\title{
Focus on 1992
}

I am pleased and honored to serve in 1992 as the 17th president of the Materials Research Society. For more than a decade I have enjoyed attending MRS meetings and using MRS publications. Since being elected to the MRS Council in 1988 and serving as MRS second vice president in 1990 and first vice president in 1991, I have been further impressed by the breadth and quality of MRS activities and by the commitment and quality of MRS volunteers and staff. We are fortunate to have such creative, capable people working on behalf of the materials research community, and as MRS president, I am particularly happy to have such excellent people helping me with the Society's work.

In addition to meetings and publications, the core of MRS, other Society activities are growing in importance and in effectiveness. High among my goals as MRS president in 1992 are the following:

- Increased effectiveness and cooperation in unifying, serving, and speaking for the materials science and engineering community, through our own Washington Office of Public Affairs, through MRS Publicity and Public Relations Committee activities, and through cooperation with other materials-related societies worldwide in the International Union of Materials Research Societies (IUMRS), and domestically in the evolving Materials Sciences Coordinating Panel, and in continuing joint sponsorship and support for the annual Washington Materials Forum.

- Broader participation in MRS by university-based scientists and engineers and by college and university students. Increasing connections between MRS and the academic materials education and research community is just as important as strengthening links between MRS and other technical societies and with government decision makers. We need strong programming in such areas as materials science and engineering education. A good example is the workshop organized by Merton Flemings and Reza Abbaschian at the 1991 Fall Meeting. MRS University Chapters must be nurtured, and optimum use must be made of MRS funds for chapter activities, student travel, short course scholarships, and student awards at the spring and fall meetings. MRS can also become a resource for curriculum development and evaluation for both undergraduate and graduate education in materials-related fields.
- Assisting MRS members in bringing excitement and knowledge of science, particularly science involving materials, into K-12 classrooms throughout the country, through the recently established MRS Ad Hoc Grassroots Education Committee and through cooperation with other technical societies which share our interest in K-12 science education.

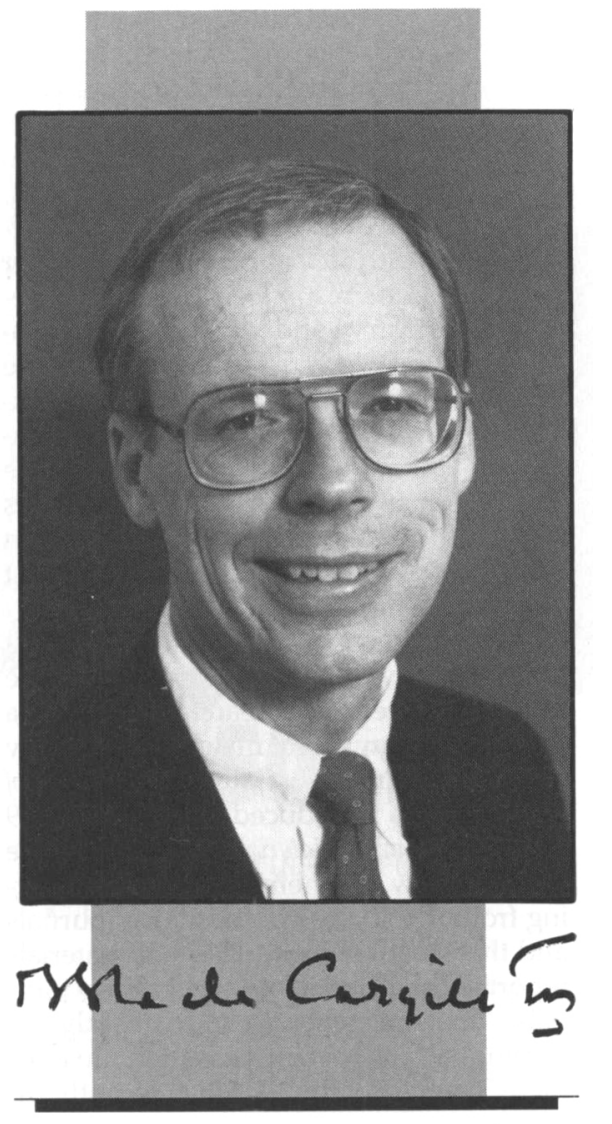

High among my goals for 1992 is to foster increased effectiveness and cooperation in unifying, serving, and speaking for the materials science and engineering community.

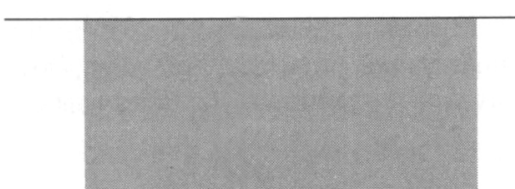

- Helping to match MRS members seeking jobs with potential employers, and providing opportunities for MRS members to maintain technical vitality through short courses as well as workshops and symposia. These services, as well as reduced registration fees for unemployed or retired MRS members, are particularly important in the current weak economy and poor job market.

- Recognizing technical achievement and professional excellence, with consistently high standards, through MRS awards-the Von Hippel award begun in 1977, the MRS Medal introduced in 1990, and the MRS Outstanding Young Investigator Award initiated in 1991. Additionally, the Turnbull Lectureship was approved by Council in 1991, and its first presentation is expected in 1992 or 1993.

All these activities-intersociety and government relations, college and university participation, K-12 science education, assistance in employment and technical vitality, and awards recognizing excellence, as well as meetings and publicationsdepend on the financial success of the Society. Funds from revenue-producing operations, such as meetings with their associated equipment exhibits, publications, and short courses, as well as revenues from membership dues and corporate contributions, support all the activities of MRS. During the general economic downturn of the last few years, maintaining a positive balance between MRS revenues and expenses has been a major challenge. Thanks to the efforts of both MRS officers and headquarters staff, important progress has been made in bringing revenues and expenses into balance in order to reverse the decrease in net worth in 1990 . Although 1991 was also a difficult year financially, cost containment measures and pricing increases achieved approximately breakeven operation. With a 1992 budget that recognizes the need for continued constraints on spending and the probability of flat revenues, and with the experience gained in coping with the problems of 1990 and 1991, the financial health of MRS and its activities should continue to improve.

I look forward to involvement in all these areas because MRS is such a vital and important organization, because the volunteers and staff of MRS bring such strong commitments and talents to their tasks, and because the needs and opportunities for the Materials Research Society have never been greater.

Slade Cargill 